\title{
EXPERIMENTAL STUDIES ON NATURAL SELECTION IN THE BUTTERFLY, MANIOLA JURTINA
}

\author{
W. H. DOWDESWELL \\ Biology Department, Winchester College
}

Received 12.x.60

ONE of the greatest advances in evolutionary thought during the last decade has been the realisation that, among polymorphic species, selection pressures may occur of far greater magnitude than had hitherto been supposed. Under favourable circumstances, genes conferring beneficial phenotypic effects are thus enabled to spread through populations with remarkable speed. This principle is admirably demonstrated by the advance of industrial melanism in the moth Biston betularia (Kettlewell, 1958) where it is clear that, over the last hundred years, selective advantages in favour of the carbonaria genotype must have averaged about 30 per cent. per annum.

Extensive studies of the butterfly, Maniola jurtina, have shown that the distribution of spots on the hind-wings (ranging from o to 5 per wing) - a phenotypic condition evidently under the control of several genes-assumes a variety of equilibria in different parts of Britain, each stabilised at a particular level. Spotting, or rather the characteristics associated with it, thus appears to be subject to the action of natural selection. During our recent investigation of spot-values in jurtina on the English Mainland (Creed et al., 1959), we encountered an extraordinary situation in which the female distribution typical of Southern England (unimodal at o spots) changed abruptly to an East Cornish stabilisation (bimodal at o and 2 spots) near the DevonCornish border, in a matter of a few hundred yards. The rapid transition from one spot-phenotype to another has now persisted for four successive years, and there seems no doubt that here we have selection pressures at work of a magnitude at least comparable with those found in polymorphic species. This view is supported by the existence of a "reverse-cline" effect in which the difference between the two populations reaches a maximum as they approach each other closely.

Clearly, there is an urgent need for a more precise analysis both of the magnitude of selective effects and of the agents involved. The following study represents an attempt to achieve this by shielding jurtina from the action of natural selection in the laboratory for a period of its life cycle and by comparing the spotting of the resulting adults with that of wild insects subjected to the full force of elimination. The breeding habits of the butterfly are unfortunately not well suited to this sort of experiment, since over-wintering takes place as a minute 
larva which spends most of its time deep down among the grass tussocks where it is quite inaccessible. However, from late April onwards the caterpillars, now half grown, become active at night and feed on the grass stems. It was from these that our laboratory stocks were derived and from which adults were obtained some seven weeks later for comparison with their wild counterparts.

\section{THE MIDDLETON POPULATION OF MANIOLA JURTINA}

The area chosen for this study is a small patch of chalk downland enclosed within Harewood Forest $(4 \mathrm{I} / 405455)$ about $2 \frac{1}{2}$ miles due east of Andover (Hampshire). The butterflies are incapable of penetrating dense woodland and the colony is thus totally isolated. The locality is divided into two roughly equal parts by a thick mass of dogwood scrub extending for several hundred yards. Marking experiments showed this to be an effective barrier to $M$. jurtina. Sampling of larvæ and adults was confined entirely to the eastern area comprising approximately i 7 acres, and referred to hereafter as Middleton East (Middleton being the name of the nearest village). From rather limited capture-recapture data, it appears that the size of the colony probably fluctuates between 3000 and Io,000 insects.

\section{(i) Females}

Extensive sampling throughout the season for the last five years has given no indication of any significant seasonal variation in spotting

TABLE I

Female samples, 1960

\begin{tabular}{|c|c|c|c|c|c|c|c|c|}
\hline \multirow{2}{*}{ Date } & \multicolumn{6}{|c|}{ Spots } & \multirow{2}{*}{$\begin{array}{l}\text { Spot } \\
\text { av. }\end{array}$} & \multirow{2}{*}{ Total } \\
\hline & 0 & I & 2 & 3 & 4 & 5 & & \\
\hline $\begin{array}{l}\text { 9.vii } \\
\text { I0.vii } \\
\text { I I.vii } \\
\text { Ig.vii } \\
\text { 22.vii } \\
\text { 23.vii } \\
\text { I8.viii }\end{array}$ & $\begin{array}{r}14 \\
3 \\
\text { I3 } \\
\text { I3 } \\
19 \\
\text { II } \\
64\end{array}$ & $\begin{array}{r}8 \\
4 \\
2 \\
2 \\
5 \\
2 \\
24\end{array}$ & $\begin{array}{r}4 \\
1 \\
3 \\
3 \\
2 \\
\text { I } \\
\text { I }\end{array}$ & $\begin{array}{r}\cdots \\
1 \\
2 \\
\cdots \\
3 \\
1 \\
3\end{array}$ & $\begin{array}{l}\cdots \\
\cdots \\
\cdots \\
\cdots \\
\cdots \\
\cdots \\
\cdots\end{array}$ & $\begin{array}{l}\cdots \\
\cdots \\
\cdots \\
\cdots \\
\cdots \\
\cdots\end{array}$ & $\begin{array}{l}0.62 \\
1.00 \\
0.70 \\
0.44 \\
0.52 \\
0.47 \\
0.53\end{array}$ & $\begin{array}{r}26 \\
9 \\
20 \\
18 \\
29 \\
15 \\
101\end{array}$ \\
\hline & 137 & 47 & 24 & 10 & $\cdots$ & $\cdots$ & 0.57 & 218 \\
\hline
\end{tabular}

$\chi_{(5)}^{2}=4.5^{8} ; \mathrm{P}=0.5$ to 0.3 (values for I to 3 spots accumulated).

(see Creed et al. (1959) for evidence of intra-seasonal variation elsewhere). However, in both 1959 and 1960 there was a suggestion of higher spot-values in the early samples, but these were far too small to sway a formal test of heterogeneity (table $\mathrm{I}$ ). As we shall see later, 
there is reason to believe that increased spot-averages among females may be a feature of all jurtina populations at the beginning of the emergence, but these are difficult to detect with certainty except in very large colonies owing to the small numbers on the wing at that time.

TABLE 2

Total female samples, 1956 -rg6o

\begin{tabular}{|c|c|c|c|c|c|c|c|c|}
\hline \multirow{2}{*}{ Year } & \multicolumn{6}{|c|}{ Spots } & \multirow{2}{*}{$\begin{array}{l}\text { Spot } \\
\text { av. }\end{array}$} & \multirow{2}{*}{ Total } \\
\hline & 0 & 1 & 2 & 3 & 4 & 5 & & \\
\hline $\begin{array}{l}1956 \\
1957 \\
1958 \\
1959 \\
1960\end{array}$ & $\begin{array}{r}93 \\
126 \\
158 \\
157 \\
137\end{array}$ & $\begin{array}{l}43 \\
41 \\
63 \\
64 \\
47\end{array}$ & $\begin{array}{l}12 \\
20 \\
38 \\
29 \\
24\end{array}$ & $\begin{array}{r}\ldots \\
3 \\
8 \\
3 \\
10\end{array}$ & $\begin{array}{c}\ldots \\
\cdots \\
1 \\
\cdots \\
\cdots\end{array}$ & $\begin{array}{l}\ldots \\
\cdots \\
\cdots \\
\cdots \\
\cdots\end{array}$ & $\begin{array}{l}0.45 \\
0.47 \\
0.62 \\
0.52 \\
0.57\end{array}$ & $\begin{array}{l}148 \\
190 \\
268 \\
253 \\
218\end{array}$ \\
\hline 1960 & 671 & $25^{8}$ & 123 & 24 & I & $\ldots$ & 0.54 & 1077 \\
\hline
\end{tabular}

From an $n \times n$ table, $\chi_{(8)}^{2}=11 \cdot 14 ; \mathrm{P}=0.2$ (values for 2 to 4 spots accumulated).

TABLE 3

Male samples, 1960

\begin{tabular}{|c|c|c|c|c|c|c|c|c|}
\hline \multirow{2}{*}{ Date } & \multicolumn{6}{|c|}{ Spots } & \multirow{2}{*}{$\begin{array}{l}\text { Spot } \\
\text { av. }\end{array}$} & \multirow{2}{*}{ Total } \\
\hline & 0 & I & 2 & 3 & 4 & 5 & & \\
\hline 26.vi & $\ldots$ & 2 & 8 & I & 2 & $\ldots$ & $2 \cdot 23$ & 13 \\
\hline 9.vii & $\dddot{1}$ & 5 & 55 & 16 & 3 & I & 2.23 & $8 \mathrm{I}$ \\
\hline Io.vii & $\ldots$ & 2 & 18 & 5 & I & $\ldots$ & $2 \cdot 19$ & 26 \\
\hline II.vii & $\ldots$ & 3 & 16 & 4 & $\ldots$ & $I$ & $2 \cdot 17$ & 24 \\
\hline Ig.vii & $\ldots$ & 1 & 14 & 5 & $\ldots$ & $\ldots$ & $2 \cdot 20$ & 20 \\
\hline 22.vii & $\ldots$ & 2 & 19 & 2 & $\ldots$ & $\ldots$ & $2 \cdot 00$ & 23 \\
\hline \multirow[t]{2}{*}{ I8.viii } & 2 & 5 & 30 & 4 & 2 & $\ldots$ & $1 \cdot 98$ & 43 \\
\hline & 3 & 20 & 160 & 37 & 8 & 2 & $2 \cdot 14$ & 230 \\
\hline
\end{tabular}

$\chi_{(3)}^{2}=2 \cdot 58 ; \mathrm{P}=0.5$ to 0.3 (values for $0+1+2$ spots and $3+4+5$ spots accumulated; also samples for $26 . v i+9 . v i i$; $10 . v i i+1$ r.vii ; $19 . v i i+22 . v i i$ grouped together).

A satisfactory feature of the Middleton population has been its remarkable stability of spotting throughout the period of study in spite of the great variations in weather from one year to the next (table 2).

The spot-averages suggest a gradual increase until 1958 , after which they levelled off and slightly declined during the two subsequent years. 


\section{(ii) Males}

As in the females, there was a hint of higher spotting among males at the beginning of the season both in r959 and 1960, but none in the previous three years. However, this was insufficient to influence a $\chi^{2}$ test (table 3 ), and there was no appreciable evidence of any intraseasonal spot-fluctuation. Unlike the females, however, there was strong heterogeneity between the annual samples- $\chi_{(6)}^{2}=21 \cdot 22$; $\mathrm{P}=0.0 \mathrm{r}$ to $0.00 \mathrm{r}$ (values for $0+\mathrm{I}$ spots and $3+4+5$ spots accumulated; samples for $195^{6}$ and 1957 grouped together (table 4). While

TABLE 4

Total male samples, 1956-1960

\begin{tabular}{|c|c|c|c|c|c|c|c|c|}
\hline \multirow{2}{*}{ Year } & \multicolumn{6}{|c|}{ Spots } & \multirow{2}{*}{$\begin{array}{l}\text { Spot } \\
\text { av. }\end{array}$} & \multirow{2}{*}{ Total } \\
\hline & 0 & I & 2 & 3 & 4 & 5 & & \\
\hline $195^{6}$ & 2 & 5 & 32 & 8 & $\cdots$ & $\ldots$ & $I \cdot 98$ & \\
\hline 1957 & 7 & 25 & 164 & 37 & 6 & $\ldots$ & $2 \cdot 04$ & $\begin{array}{r}41 \\
239\end{array}$ \\
\hline 1958 & 6 & 21 & 285 & $9^{\mathrm{i}}$ & 20 & 3 & $2 \cdot 25$ & 426 \\
\hline 1959 & 4 & 12 & ז68 & $5^{6}$ & 12 & I & $2 \cdot 25$ & 253 \\
\hline 1960 & 3 & 20 & 160 & 37 & 8 & 2 & $2 \cdot 14$ & 230 \\
\hline
\end{tabular}

maintaining much the same general pattern of variation in spot-average over the five years, the fluctuations among males thus appear to have been more marked than those occurring in the females.

\section{COLLECTION AND REARING OF WILD LARVA}

After hibernation, the larvæ start feeding again in late April, by which time they have attained a length of about $\mathrm{I} \mathrm{cm}$. Virtually nothing is known of the microclimate in the grass tufts where the animals live, but it is clear that their activity is closely related to temperature and humidity. Thus we found that for successful collecting, a minimum temperature of $50^{\circ} \mathrm{F}$. was needed, also a fairly heavy dew. The larvæ are nocturnal and feed on a variety of grasses which at Middleton are chiefly Helictotrichon pubescens and Brachypodium sylvaticum. Their density is never very high and we found it quite impracticable to collect them by torchlight as is frequently advocated in the entomological literature. The only reasonably efficient collecting device is a sweeping net mounted on a stout stick, but even with this the accumulation of a reasonable sample was a fairly laborious undertaking. Thus four collectors working for an hour and a half after sunset were fortunate if they managed to secure 40 larvæ. The difficulties of collecting are aggravated by the remarkable sensitivity of the caterpillars to touch or even the slightest impact of a net on the grass stems where they are feeding. Their immediate reaction is 
invariably to curl up and drop down into the herbage below. When sweeping, therefore, the passage of the net must be sufficiently rapid to defeat this alarm reaction.

Rearing the larvæ in captivity presents little difficulty and they thrive in the laboratory on the appropriate grasses grown in pots. Mortality during 1957 and $195^{8}$ was relatively low (table 5) and in most instances the cause of death was uncertain. However, in 1959 and ig6o the proportion of fatalities rose steeply to roughly a third. As will be seen from table 5 , the reason for this was largely parasitism by the Hymenopteran, Apanteles tetricus, of larvæ collected from early June onwards. Although not identified at the time, there now seems little doubt that more than three-quarters of the deaths recorded as due to "parasitisation" among larvæ collected in 1958 after the

TABLE 5

Mortality among reared M. jurtina from Middleton East, r957-rg60

\begin{tabular}{|c|c|c|c|c|c|}
\hline Year & $\begin{array}{l}\text { Period of } \\
\text { collecting }\end{array}$ & $\begin{array}{l}\text { Total } \\
\text { larvæ }\end{array}$ & $\begin{array}{c}\text { Mortality of } \\
\text { larvæ } \\
\text { (per cent.) }\end{array}$ & $\begin{array}{l}\text { Per cent. of } \\
\text { mortality due to } \\
\text { Apanteles }\end{array}$ & $\begin{array}{l}\text { Mortality of } \\
\text { pupæ } \\
\text { (per cent.) }\end{array}$ \\
\hline 1957 & I9.v.-3o.v. & 39 & $5 \cdot 1$ & $\cdots$ & $2 \cdot 7$ \\
\hline r958 & $\begin{array}{l}\text { 8.v.-3r.v. } \\
\text { r.vi.-16.vi }\end{array}$ & $\begin{array}{r}139 \\
63\end{array}$ & $\begin{array}{r}8 \cdot 6 \\
14 \cdot 2\end{array}$ & $77 \cdot 8$ ? & $9 \cdot 5$ \\
\hline I959 & $\begin{array}{l}\text { 9.v.-3r.v. } \\
\text { I.vi.-g.vii }\end{array}$ & $\begin{array}{r}48 \\
220\end{array}$ & $\begin{array}{l}10 \cdot 4 \\
31.8\end{array}$ & $7 \ddot{8} \cdot 6$ & $6 \cdot 2$ \\
\hline 1960 & $\begin{array}{l}\text { 26.iv.-3r.v. } \\
\text { r.vi.-18.vii }\end{array}$ & $\begin{array}{l}\text { IOI } \\
259\end{array}$ & $\begin{array}{l}19 \cdot 8 \\
39 \cdot 3\end{array}$ & $\begin{array}{r}5 \cdot 0 \\
73 \cdot 5\end{array}$ & $10 \cdot 9$ \\
\hline
\end{tabular}

beginning of June, were also inflicted by Apanteles. The reason for the lack of parasitism in 1957 is clear enough, for no larvæ were collected after the end of May. The isolation of the parasite for identification proved a comparatively simple matter for the fully grown grubs were frequently observed emerging from stricken jurtina larvæ and the characteristic white cocoons which they spin prior to pupation were clearly visible on the grass stems or surrounding their dying host. Identification of the emerging adults as Apanteles tetricus was kindly undertaken by Mr G. E. J. Nixon of the Commonwealth Institute of Entomology. With a little experience we found it was often possible to tell in the field which larvæ were likely to be parasitised, owing to their inability to curl up in the characteristic manner already described.

Mortality among the pupæ during the four years was consistently at a fairly low level (table 5). The causes of death are unknown but, without exception, failure occurred at the pigmented stage, i.e. a day or so prior to emergence. There was no evidence of parasitism carried over from the larval stage. 


\title{
3. COMPARISON OF REARED AND FLYING ADULTS
}

\author{
(i) Females
}

The samples of reared and flying $M$. jurtina from Middleton East are summarised and compared in table 6.

The most obvious discrepancy concerns the reared insects emerging early which, in all four years, are far more highly spotted than would

TABLE 6

Comparison of reared and flying female M. jurtina from Middleton East, 1957-1960

\begin{tabular}{|c|c|c|c|c|c|c|c|c|c|c|c|}
\hline \multirow{2}{*}{ Year } & \multirow{2}{*}{$\begin{array}{l}\text { Origin } \\
\text { of } \\
\text { sample }\end{array}$} & \multirow{2}{*}{ Date } & \multicolumn{6}{|c|}{ Spots } & \multirow{2}{*}{$\begin{array}{l}\text { Spot } \\
\text { av. }\end{array}$} & \multirow{2}{*}{ Total } & \multirow{2}{*}{$\begin{array}{l}\text { Comparison of reared } \\
\text { and flying }\end{array}$} \\
\hline & & & 0 & I & 2 & 3 & 4 & 5 & & & \\
\hline 1957 & $\begin{array}{l}\mathbf{R} \\
\mathbf{F}\end{array}$ & $\begin{array}{l}\text { 22.vi-3o.vii } \\
3^{0 . v i-2 . i x}\end{array}$ & $\begin{array}{r}5 \\
126\end{array}$ & $\begin{array}{r}6 \\
41\end{array}$ & $\begin{array}{r}8 \\
20\end{array}$ & $\dddot{3}$ & $\cdots$ & $\begin{array}{l}\cdots \\
\cdots\end{array}$ & $\begin{array}{l}1 \cdot 16 \\
0 \cdot 47\end{array}$ & $\begin{array}{r}19 \\
190\end{array}$ & $\chi_{(1)}^{2}=11.81 ; P<0.001$ \\
\hline $195^{8}$ & $\begin{array}{l}\mathbf{R} \\
\mathrm{R} \\
\mathrm{F}\end{array}$ & $\begin{array}{l}\text { 3.vii-12.vii } \\
\text { 13.vii-3.viii } \\
\text { 5.vii-16.viii }\end{array}$ & $\begin{array}{r}6 \\
14 \\
158\end{array}$ & $\begin{array}{r}4 \\
21 \\
63\end{array}$ & $\begin{array}{r}10 \\
99 \\
3^{8}\end{array}$ & $\begin{array}{l}5 \\
2 \\
8\end{array}$ & $\begin{array}{l}\text { I } \\
\text { I } \\
\text { I }\end{array}$ & $\begin{array}{l}\cdots \\
\cdots \\
\cdots\end{array}$ & $\begin{array}{l}1 \cdot 65 \\
1 \cdot 04 \\
0 \cdot 62\end{array}$ & $\begin{array}{r}26 \\
47 \\
268\end{array}$ & $\begin{array}{l}\chi_{(2)}^{2}=27.57 ; P<0.001 \\
\chi_{(2)}^{2}=14.32 ; P<0.001\end{array}$ \\
\hline I 959 & $\begin{array}{l}\mathrm{R} \\
\mathrm{R} \\
\mathrm{F}\end{array}$ & $\begin{array}{l}\text { 22.vi-22.vii } \\
\text { 23.vii-16.viii } \\
\text { 4.vii-16.viii }\end{array}$ & $\begin{array}{r}15 \\
41 \\
157\end{array}$ & $\begin{array}{r}9 \\
64\end{array}$ & $\begin{array}{l}9 \\
8\end{array}$ & $\cdots$ & $\ldots$ & $\cdots$ & $\begin{array}{l}0 \cdot 90 \\
0 \cdot 55 \\
0 \cdot 52\end{array}$ & $\begin{array}{r}41 \\
60 \\
253\end{array}$ & $\begin{array}{ll}\chi_{(2)}^{2}=9.76 ; & P=0.01 \\
\text { to } 0.001 & \\
\chi_{(2)}^{2}=3.08 ; & P=0.3 \\
\text { to } 0.2 & \end{array}$ \\
\hline 1960 & $\begin{array}{l}\mathrm{R} \\
\mathrm{R} \\
\mathrm{F}\end{array}$ & $\begin{array}{l}\text { 20.vi-20.vii } \\
\text { 21.vii-24.viii } \\
\text { 9.vii-18.viii }\end{array}$ & $\begin{array}{r}16 \\
52 \\
137\end{array}$ & $\begin{array}{l}11 \\
31\end{array}$ & $\begin{array}{l}10 \\
7\end{array}$ & 10 & $\cdots$ & $\cdots$ & $\begin{array}{l}1 \cdot 10 \\
0.61 \\
0 \cdot 57\end{array}$ & $\begin{array}{r}42 \\
94 \\
218\end{array}$ & $\begin{array}{l}\chi_{(2)}^{2}=11.57 ; P=0.01 \\
\text { to } 0.001 \\
\chi_{(2)}^{2}=4.73 ; \quad P=0.1 \\
\text { to } 0.05\end{array}$ \\
\hline
\end{tabular}

In column 2, $\mathrm{R}=$ reared ; $\mathrm{F}=$ flying.

In calculating $\chi^{2}$ for the 1957 samples, values at $I$ to 3 spots have been accumulated. In all the remaining calculations, values for 2, 3 and 4 spots have been grouped together.

have been expected judging by their wild counterparts. As the season proceeded, so the spot-values began to fall, and in both 1959 and ig6o the reared adults emerging from the third week in June onwards showed a spot-distribution similar to that of the flying insects. The situation in 1959 is shown graphically in fig. 1 . It will be recalled that early June was the time when the infection of larvæ by Apanteles first showed itself. The reared butterflies exhibiting wild-type spotting were thus derived from those caterpillars which managed to remain uninfected. 
We are here faced with a remarkable situation, that by selective parasitism, Apanteles tetricus plays a major part in controlling spotdistribution in the adult females of $M$. jurtina.
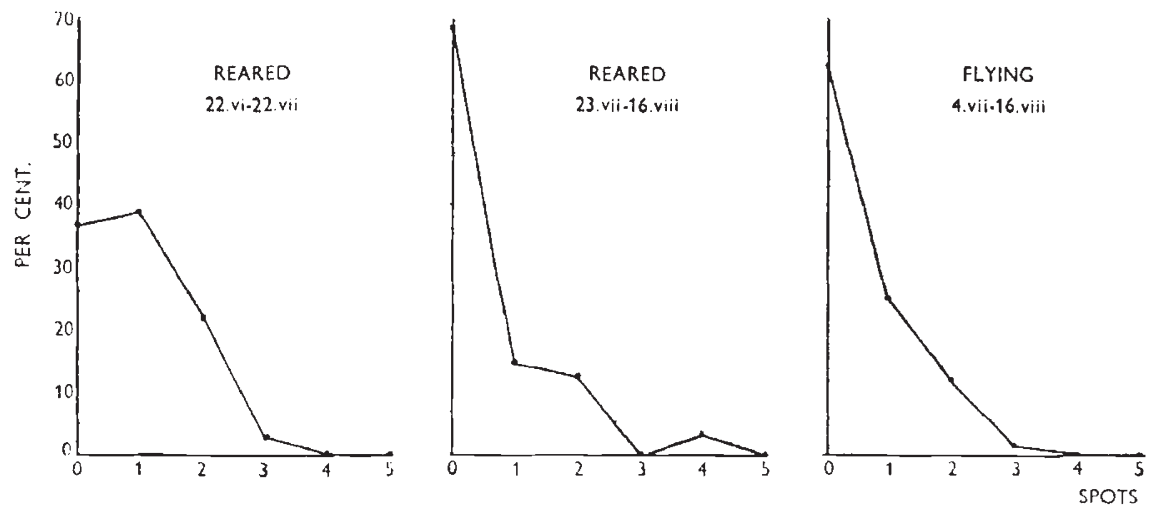

Fig. I.-Spot-distributions in reared and flying females; 1959 .

(ii) Males

The result of comparing reared and flying males is less striking than in the females (table 7). Throughout the four years there has

TABLE 7

Comparison of reared and fying male M. jurtina from Middleton East,

1957-1960

\begin{tabular}{|c|c|c|c|c|c|c|c|c|c|c|c|}
\hline \multirow{2}{*}{ Year } & \multirow{2}{*}{$\begin{array}{c}\text { Origin } \\
\text { of } \\
\text { sample }\end{array}$} & \multirow{2}{*}{ Date } & \multicolumn{6}{|c|}{ Spots } & \multirow{2}{*}{$\begin{array}{l}\text { Spot } \\
\text { av. }\end{array}$} & \multirow{2}{*}{ Total } & \multirow{2}{*}{$\begin{array}{l}\text { Comparison of reared } \\
\text { and flying }\end{array}$} \\
\hline & & & 0 & I & 2 & 3 & 4 & 5 & & & \\
\hline 1957 & $\begin{array}{l}\mathrm{R} \\
\mathrm{F}\end{array}$ & $\begin{array}{l}\text { Ig.vi-1 } 4 \cdot \text { vii } \\
\text { I 8.vi-2.ix }\end{array}$ & $\begin{array}{l}\cdots \\
7\end{array}$ & $\begin{array}{l}\cdots \\
25\end{array}$ & $\begin{array}{r}14 \\
164\end{array}$ & $\begin{array}{r}2 \\
37\end{array}$ & 6 & $\cdots$ & $\begin{array}{l}2 \cdot 24 \\
2 \cdot 04\end{array}$ & $\begin{array}{r}17 \\
239\end{array}$ & $\begin{array}{l}\chi_{(1)}^{2}=0.001_{3} ; P=0.9^{8} \\
\text { to } 0.95\end{array}$ \\
\hline $195^{8}$ & $\begin{array}{l}\mathrm{R} \\
\mathrm{F}\end{array}$ & $\begin{array}{l}\text { 27.vi-3.viii } \\
\text { 5.vii-16.viii }\end{array}$ & $\begin{array}{c}\cdots \\
6\end{array}$ & $\begin{array}{r}4 \\
21\end{array}$ & $\begin{array}{r}57 \\
285\end{array}$ & $\begin{array}{l}14 \\
91\end{array}$ & 20 & $\begin{array}{l}3 \\
3\end{array}$ & $\begin{array}{l}2 \cdot 29 \\
2 \cdot 25\end{array}$ & $\begin{array}{r}80 \\
426\end{array}$ & $\begin{array}{l}x_{(1)}^{2}=0.31 ; \quad P=0.7 \\
\text { to } 0.5\end{array}$ \\
\hline 1959 & $\begin{array}{l}\mathrm{R} \\
\mathrm{F}\end{array}$ & $\begin{array}{l}\text { I8.vi-I.viii } \\
\text { 4.vii-r6.viii }\end{array}$ & $\begin{array}{c}\cdots \\
4\end{array}$ & $\begin{array}{r}5 \\
12\end{array}$ & $\begin{array}{r}47 \\
\mathbf{1} 68\end{array}$ & $\begin{array}{l}\text { 10 } \\
56\end{array}$ & $\begin{array}{r}4 \\
12\end{array}$ & I & $\begin{array}{l}2 \cdot 24 \\
2 \cdot 25\end{array}$ & $\begin{array}{r}67 \\
253\end{array}$ & $\begin{array}{l}\chi_{(1)}^{2}=0.425 ; \quad P=0.7 \\
\quad \text { to } 0.5\end{array}$ \\
\hline 1960 & $\begin{array}{l}\mathrm{R} \\
\mathrm{F}\end{array}$ & $\begin{array}{l}\text { 20.vi -20.viii } \\
\text { 26.vi-18.viii }\end{array}$ & $\begin{array}{c}\cdots \\
3\end{array}$ & 20 & $\begin{array}{r}53 \\
160\end{array}$ & $\begin{array}{l}17 \\
37\end{array}$ & $\begin{array}{l}4 \\
8\end{array}$ & $\begin{array}{l}\cdots \\
2\end{array}$ & $\begin{array}{l}2 \cdot 30 \\
2 \cdot 14\end{array}$ & $\begin{array}{r}76 \\
230\end{array}$ & $\begin{array}{l}\chi_{(2)}^{2}=5.13 ; \quad P=0.1 \\
\text { to } 0.05\end{array}$ \\
\hline
\end{tabular}

In column 2, $\mathrm{R}=$ reared ; $\mathrm{F}=$ flying.

In calculating $\chi^{2}$ for the 1957,1958 and 1959 samples, values for $0+1+2$ and $3+4+5$ spots have been accumulated. In the 1960 data, $0+1$ and $3+4+5$ spot-values have been grouped together. 
been no indication of intra-seasonal variation in spotting among reared adults nor any evidence of divergence between them and their flying counterparts. The nearest approach to this was in I96o but, as will be seen from table 7 , the difference did not attain the level of formal significance. The comparison for 1959 provides a typical instance and is presented graphically in fig. 2. The role of Apanteles in relation to male spot-values thus remains obscure; but it seems
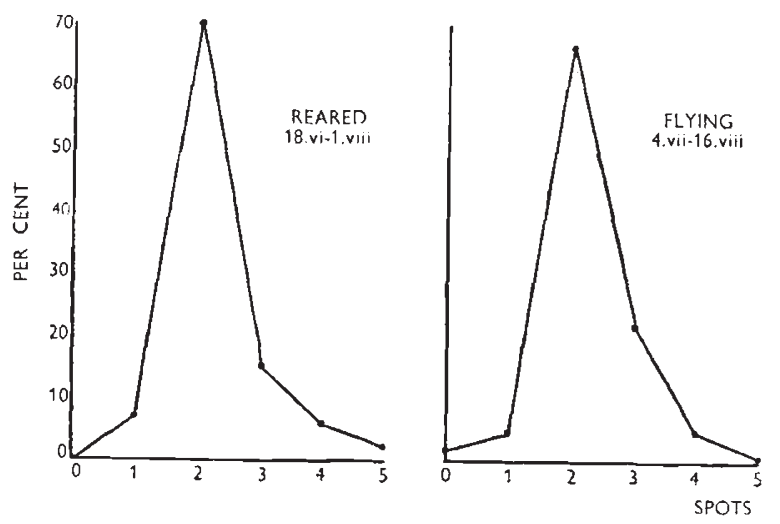

FIG. 2.-Spot-distributions in reared and flying males; 1959

that the genes controlling spotting must exert different effects in the male from those in the female in influencing susceptibility to Apanteles infection.

\section{RANDOM SAMPLING OF LARVA}

Any valid comparison of reared and flying jurtina rests on the assumption that a method involving sweeping at night selects the larvæ at random. If spotting in the adult is under genetic control, as it clearly must be (pp. 48-50), the genes concerned could affect some aspects of behaviour as well. For instance, they might determine the tendency of a larva to feed high up on a grass stem thus influencing its liability to capture. Such an arrangement might well account for the excess of high-spotted females obtained at the beginning of the emergence.

To test this hypothesis, larvæ captured in 1959 were divided according to their feeding behaviour in the breeding cages at night into two groups-high feeding and low feeding. The division was obviously rather an artificial one but, as far as was possible, we chose certain arbitrary points on the food plants, to enable us to decide unequivocally into which category each larva should be placed. The cages were examined on four successive nights at a time when collecting at Middleton would have taken place (between 10.0 and I 0.45 p.m.). The results are analysed in table 8.

Within the limitations of this rather crude experiment, it seems clear that the majority of larvæ exhibit a fairly consistent form of 
feeding behaviour under laboratory conditions. Whether this represents faithfully what happens in the wild state is, of course, impossible to say. The spot-distributions of the two resulting groups of adults when compared showed no significant difference between them. For the males $\chi_{(1)}^{2}=0.84$ with $\mathrm{P}=0.5$ to 0.3 , and in the females $\chi_{(1)}^{2}=0.02$;

TABLE 8

Feeding behaviour of larve from Middleton East, 1959

\begin{tabular}{|c|c|c|c|c|c|}
\hline \multirow{2}{*}{ Date } & \multicolumn{4}{|c|}{ Larvæ selected for high feeding } & \multirow{2}{*}{$\begin{array}{c}\text { Departure from } \\
\text { equality }\end{array}$} \\
\hline & Feeding high & Percentage & Total & Standard error & \\
\hline $\begin{array}{l}\text { I } 7 . v i \\
\text { I8.vi } \\
\text { Ig.vi } \\
\text { 20.vi }\end{array}$ & $\begin{array}{l}26 \\
23 \\
20 \\
23\end{array}$ & $\begin{array}{l}79 \cdot 79 \\
69 \cdot 70 \\
74 \cdot 07 \\
65 \cdot 71\end{array}$ & $\begin{array}{l}33 \\
33 \\
27 \\
35\end{array}$ & $\begin{array}{l} \pm 7 \cdot 11 \\
\pm 8 \cdot 00 \\
\pm 8 \cdot 43 \\
\pm 8 \cdot 03\end{array}$ & $\begin{array}{l}\text { S. } \\
\text { S. } \\
\text { S. } \\
\text { N.S. }\end{array}$ \\
\hline \multirow{2}{*}{ Date } & \multicolumn{4}{|c|}{ Larvæ selected for low feeding } & \multirow{2}{*}{$\begin{array}{c}\text { Departure from } \\
\text { equality }\end{array}$} \\
\hline & Feeding low & Percentage & Total & Standard error & \\
\hline $\begin{array}{l}\text { 1 } 7 . \mathrm{vi} \\
\text { 18.vi } \\
19 . \mathrm{vi} \\
20 . \mathrm{vi}\end{array}$ & $\begin{array}{l}41 \\
24 \\
28 \\
14\end{array}$ & $\begin{array}{l}89 \cdot 13 \\
53 \cdot 30 \\
77 \cdot 78 \\
51 \cdot 85\end{array}$ & $\begin{array}{l}46 \\
45 \\
36 \\
27\end{array}$ & $\begin{array}{l} \pm 4.59 \\
\pm 5.44 \\
\pm 6 \cdot 93 \\
\pm 9 \cdot 62\end{array}$ & $\begin{array}{l}\text { S. } \\
\text { N.S. } \\
\text { S. } \\
\text { N.S. }\end{array}$ \\
\hline
\end{tabular}

In column $6, \mathrm{~S} .=$ significant, and N.S. = not significant.

$P=0.9$. There thus appears to be good reason for assuming that the sampling of the larvæ in relation to their feeding behaviour was at random in so far as the eventual spotting of the adults was concerned.

\section{DISCUSSION}

The Middleton population of female Maniola jurtina has proved to be ideal for a study of the influence of natural selection on spotdistribution since inter- and intra-seasonal variations in spotting have been virtually absent. By contrast, the imagines reared from wild larvæ have exhibited striking intra-seasonal heterogeneity. As a result of four years' work it is now clear that the emergence of adult females conforms to a distinct pattern. Those appearing from late June to mid-July develop from larvæ unaffected by parasitism and are characterised by a spot-average about double that occurring in the wild state. Thereafter, spotting rapidly declines and, among the adults derived from larvæ which have been subject to a drastic elimination through parasitism by Apanteles tetricus, the spot-distribution is identical with that of the flying population. This is well demonstrated by the results obtained in 1959 and 1960 (table 6 and fig. I). 
In $195^{8}$ late larval mortality was much reduced compared with the two following years (table 5). As the emergence proceeded the spotvalues dropped, but they never resembled those in nature. In I957, larva collecting was confined to May, so a lack of parasitism and a high level of spotting among the emergent females were to be expected (table 6).

Using an extension of the method described by Woolf (1954), it is possible to calculate the selection pressures operating in nature against "spotted" female jurtina emerging early. From the most extensive data available, those for 1959 and 1960 , and using 95 per cent. fiducial limits, it appears that the selective elimination of individuals with two spots and over compared with that of unspotted adults in 1959 was 69 per cent. (fiducial limits $87-26$ per cent.), and in 1960 attained a value of 74 per cent. (fiducial limits 88-4I per cent.). In other words a larva or pupa whose genotype would cause it to become a female with 2 or more spots, had approximately a 70 per cent. chance of being eliminated by Apanteles, or in some other way during the remaining seven weeks or so of pre-imaginal life, compared with one carrying genes which would cause it to become a female at o spots. Selection pressures of this order might well account for the abrupt transition in spotting which we have encountered on the borders of Devon and Cornwall.

Information obtained from reared Middleton larvæ provides a ready explanation of the occurrence of "intra-seasonal shift" encountered at Ipswich, Burham Down and elsewhere (Creed et al., 1959). It is noteworthy that in all these localities the trend of spotting, on occasions when it fluctuates intra-seasonally, is invariably from high values at the beginning of the season to lower ones later on, never in the reverse direction. We have seen that at Middleton the jurtina population is subject to great selection pressures, so that an excess of high spot-value females never gets a chance of showing itself. However, should the severity of selection be relaxed, it is the early, high-spotted specimens which would benefit out of all proportion. It is perhaps worth noting here that in certain Irish colonies of jurtina, selection against high spotting has been even more severe than at Middleton, with the result that values of 2 spots and over seem almost to have been eliminated (Dowdeswell and Ford, 1953).

The situation in the males is more difficult to understand. There is no doubt that "intra-seasonal shift" occurs in some colonies just as it does in the females; there has even been a hint of it at Middleton, but variations there have been too small to attain statistical significance. Like the females, higher spotting at the beginning of the season is invariably the rule in the few wild populations known to fluctuate seasonally elsewhere in England. However, experience with regard to the reared Middleton larvæ shows that spot-values are no higher at the beginning of the summer than they are later on. Moreover, the spot-distribution among reared adults shows no tendency whatever 
to depart from that of wild insects. It may well be that other phenotypic effects associated with spotting and subject to selection may differ in the male from those in the female. Perhaps the system of polygenes controlling spot-values has varying effects and is differentially selected in the two sexes.

Another aspect of our findings at Middleton bears on the possibility of explaining spotting in $M$. jurtina on an environmental rather than a genetic basis, as has often been suggested. We have seen how in I959 and I96o, the spotting of reared females was extremely different from imagines caught flying (table 6 and fig. I), with the exception of those appearing at the end of the emergence, the survivors of otherwise parasitised larvæ, whose spot-distribution was the same as the wild insects. Now it might be argued that reared butterflies could be expected to differ from caught ones, since the two had been bred in entirely different environments. If this were so, how could the females emerging late show spotting identical with that in nature? Admittedly, this might be explained on the assumption that the late emergers resemble those flying because they are derived from larvæ found later which have not, therefore, been subject to laboratory conditions for so long. Alternatively, the late larvæ might differ from the earlier ones in some way (their lateness being an aspect of this difference), and therefore fail to react to laboratory conditions in the same manner. The answer to this argument is to be found in table 5, where it will be seen that in 1958 the larval mortality due to parasitism was less than half that in 1959 and r96o. The spotting of adults emerging late in $195^{8}$ bore no resemblance to those flying at Middleton (table 6).

K. G. McWhirter has pointed out to me a number of other features of spotting in $M$. jurtina which would be hard to explain on an environmental basis:

(i) The normal widespread stabilisation of jurtina populations such as has occurred at Middleton and elsewhere.

(ii) The highly significant correlation between the spot-distribution in male and female populations (McWhirter, 1957).

(iii) The abundant evidence that one sex tends to follow the other where spot changes do occur, as happened at Middleton East to a small extent during the years 1956I959.

(iv) The rapid change-over from one form of spotting to another which takes place in the vicinity of the Devon-Cornwall border.

It is indeed unfortunate that so little is known about the ecology of Apanteles tetricus beyond the bare fact that its attacks seem to be mainly confined to butterflies of the family Satyridx. From the 
evidence provided by the Middleton larvæ, certain obvious questions arise :

(i) If the parasite infects both male- and female-producing larvæ, as it must, judging by the sex-ratio, why are its effects on spotting so different in the two sexes?

(ii) What enables it to select larvæ destined to give rise to spotted females in preference to those with no spots? Or is the parasite more viable in one kind of body than in another?

(iii) At what stage in the life of a jurtina larva does parasitic infection occur?

The fact that parasitism is not evident among the larvæ destined to give rise to the earliest adults suggests a subtle synchronisation of the life cycles of parasite and host to ensure that a supply of adequately grown jurtina caterpillars is available by the time the adult Apanteles emerge. Clearly, there is an immense field here for further investigation.

Finally, an important genetic question arises in relation to the great selection pressures exerted on spotted females. If the relative elimination rate of female jurtina with two spots and over is of the order of 70 per cent., why have not the gene systems concerned disappeared altogether? One explanation seems to be that, while the genes for spotting are advantageous in the male (particularly the 2-spot condition), they are disadvantageous in the female. Thus, as fast as the spot-genotypes are eliminated by Apanteles in the female they are reintroduced for the next generation by the males in pairing. Alternatively, the genes for spotting may have advantages balancing the effect of Apanteles. Support for an explanation on a selectionist basis is provided on the one hand by the situation in Ireland, where the genes for female spotting have been almost eliminated, and by that in East Cornwall on the other where the high spot-values are at a relative advantage.

Such a mechanism is, in a sense, rather "inefficient" but, as E. B. Ford points out, it is hardly more so than the many polymorphisms which maintain in the heterozygous state genes that are disadvantageous when homozygous. As a result of breeding experiments which we are carrying out at present, we hope before long to be able to analyse such problems further.

\section{SUMMARY}

I. An isolated colony of the butterfly Maniola jurtina at Middleton East, near Andover (Hampshire) has been studied intensively for a period of five years from the point of view of the distribution of individuals with variable numbers of spots on the underside of the hind-wings. This is a character which responds readily to the action of natural selection. 
2. By obtaining larvæ from the same locality and rearing them in the laboratory, it was possible to compare spot-values of wild insects with those shielded from the action of selection during the last seven weeks or so of pre-imaginal life.

3. Reared females from larvæ collected in May and early June invariably carried an excess of spots when compared with their freeflying counterparts. Those appearing later on exhibited a spotdistribution similar to the wild type.

4. Evidence is presented to show that the principal selective agent responsible for the reduction in spotting under natural conditions is the Hymenopterous parasite Apanteles tetricus. This was found to inflict a high mortality among larvæ collected from about the second week in June onwards.

5. Among male jurtina, there is no distinction between the spotdistribution of wild and reared adults. This suggests that the adaptive significance of spotting varies in the two sexes. It may even be under the control of different sets of polygenes.

6. An experiment designed to test the randomness of samples of wild larvæ collected by sweeping with a net at night shows that, on the whole, the larvæ are fairly consistent in their feeding habits. However, there is no indication that a tendency to feed high up on the grass stems and hence to be more easily captured, is in any way related to the spot-distribution of the resulting adults of either sex.

7. Using an extension of a calculation devised by Woolf, it is shown that selection pressures of the order of 70 per cent. operate during the last seven weeks of pre-imaginal life against larvæ and pupæ destined to give rise to females with two or more spots. Such elimination is of the order of magnitude necessary to explain the abrupt transition from a unimodal to a bimodal distribution which is known to occur in the vicinity of the Devon-Cornwall border.

8. The occurrence of an excess of highly spotted females at the beginning of the emergence provides a ready explanation of the phenomenon of "intra-seasonal shift" observed among both sexes in M. jurtina populations elsewhere. The reason for such fluctuations in males still remains obscure.

9. It is pointed out that the findings at Middleton render any suggestion that spotting in $M$. jurtina may be under the control of environmental stimuli (as opposed to a genetic mechanism) virtually untenable.

ro. Various outstanding problems are considered concerning the mechanism of parasitisation by Apanteles tetricus.

rr. Suggestions are made of ways in which high-spot female genotypes may be perpetuated in the face of severe adverse selection pressures.

Acknowledgments. - It is a pleasure to be able to record my gratitude to various organisations and individuals who have helped me with this work. To Captain A. S. Wills I am particularly grateful for his permission to work in Harewood 
Forest. The Royal Society has kindly contributed financial help for equipment and travelling, while "Shell " Research Ltd. have provided me with a calculating machine. My thanks are also due to Dr E. B. Ford, P.R.s., and Mr K. G. McWhirter for numerous stimulating discussions. Both of them have read the typescript of this paper and have offered many valuable suggestions. Mr McWhirter also kindly assisted me with the calculations. Mr G. E. J. Nixon of the Commonwealth Institute of Entomology was responsible for the identification of Apanteles tetricus, and provided me with such references to the literature as were available.

The collection of larvæ and adults of $M$. jurtina in numbers sufficient for work of this kind is a laborious and time-consuming operation, and I am fully aware of the debt I owe to a large body of helpers. In particular I would like to thank my family, numerous members of Winchester College Natural History Society, and my laboratory assistant $\mathrm{Mr} \mathrm{A}$. S. Mitchener (and, on occasions, his family as well) for all their valuable contributions. Mr Mitchener took a particularly active part in the larva collecting at night and was largely responsible for the design and construction of the special nets used for the purpose.

\section{REFERENCES}

CREED, E. R., DOWDESWELL, W. H., FORD, E. B., AND MCWHIRTER, K. G. I959. Evolutionary studies on Maniola jurtina: the English mainland 1956-57. Heredity, I3, 363-39I.

DOWDESWELL, W. H., AND FORD, E. B. 1953. The influence of isolation on variability in the butterfly, Maniola jurtina. Symposia Soc. Exp. Biol., 7, 254-273.

KETTLEWELL, H. B. D. 1958. A survey of the frequencies of Biston betularia (L.), (Lep.), and its melanic forms in Great Britain. Heredity, 12, 51-72.

McWHTRTER, K. G. 1957. A further analysis of variability in Maniola jurtina. Heredity, II, 359-37I.

woolf, B. 1955. On estimating the relation between blood group and disease. Ann. Human Genetics, 19, 25 I-253. 